\title{
Landare eta arrainen ekoizpen jasangarrirako akuaponia sistema baten garapena Tenebrio molitor intsektuaren larbak erabiliz
}

\author{
Development of an aquaponics system for sustainable plant and fish \\ production through Tenebrio molitor larvae
}

\author{
Maite Arregi ${ }^{1,2}$, Beñat Subinas ${ }^{2}$, Oier Elissalt ${ }^{2}$, Oihane Arrieta ${ }^{2}$, Leire Oreja ${ }^{2}$, \\ Maria Jose Barriola ${ }^{2}$, Ainara Saralegi*3 \\ ${ }^{1}$ Farmazia Fakultatea, Euskal Herriko Unibertsitatea (UPV/EHU) \\ ${ }^{2}$ Tknika, Ikerkuntza eta Berrikuntza aplikaturiko zentrua Lanbide Heziketan, \\ Orereta, Euskal Herria \\ ${ }^{3}$ Vitoria-Gasteizko Ingeniaritza Eskola, Euskal Herriko Unibertsitatea (UPV/EHU)
}

\begin{abstract}
LABURPENA: Akuaponia akuikultura eta hidroponiaren konbinaketaren bidez arrainak zein landareak ekoizteko birzirkulazio-sistema bat da, non bakterio nitrifikatzaileek arrainek iraitzitako hondakin metabolikoak landareentzat ezinbertzekoak diren mantenugai bihurtzen dituzten. Akuikultura zein hidroponia sistema konbentzionalekin alderatuta, akuaponia sistemak ingurumen-inpaktu zein uraren erabilera murritzagoa aurkezten du. Hala eta guztiz ere, akuaponia sistemak arrain-irinarekiko daukan menpekotasuna nabarmentzekoa da. Hori dela eta, lan honetan, Tenebrio molitor (TM) intsektu espeziearen larbak arrainen dietan proportzio ezberdinetan gehitu dira (\% 0,\% 25 eta $\% 50)$, honek arrain-irina ordezkatzeko duen gaitasuna zehazteko ortzadar-amuarrainez (Oncorhynchus mykiss) eta letxugez (Lactuca sativa) osaturiko akuaponia sistema batean. Horretarako, dieta ezberdinekin elikaturiko akuaponia sistemetan uraren propietate fisiko-kimikoak (tenperatura, $\mathrm{pHa}$, eroankortasun elektrikoa, eta nitrogeno konposatuen kontzentrazioa) eta ortzadar-amuarrainen zein letxugen hazkuntza ebaluatu dira. Uraren parametroei dagokienez, nahiz eta parametro batzuk maila optimoa gainditu, ez dute amuarrainen zein letxugen hazkuntzan eragin, sistema oro har orekan mantendu baita. Aipatzekoa da TM larbak gehitu ez diren tangetan letxugen hazkuntza handiagoa izan dela, baina TM larbak \% 25ean gehitu direnean amuarrainen hazkuntzan hobekuntza nabarmen bat ikusi dela, eta horrela, egiaztatu da TM espeziearen larbek arrain-irinean oinarritutako pentsua ordezkatzeko duten ahalmena. HITZ GAKOAK: akuaponia, akuikultura, hidroponia, Tenebrio molitor, ekonomia zirkularra.
\end{abstract}

ABSTRACT: Aquaponics is the combination of aquaculture and hydroponic for the production of fish and plants, where thanks to a recirculation system, nitrifying bacteria convert the metabolic residues excribed by fish in nutrients irreplaceable for plants. Comparing with conventional aquaculture and hydroponic systems, the aquaponics system generates less environmental impact and uses much less water. However, the dependence of the aquaponics system on fish flour as fishmeal is noteworthy. Thereby, in this work, the larvae of Tenebrio molitor (TM) insect have been included in different proportions $(0,25$ and $50 \%)$ in an aquaponics system formed by rainbow trout (Oncorhynchus mykiss) and lettuce (Lactuca sativa), in order to determine the capacity of TM to replace fish flour. To this end, the physico-chemical properties of water (temperature, $\mathrm{pH}$, electrical conductivity and concentration of nitrogen compounds) and the growth of rainbow trout and lettuce in aquaponics systems fed with different diets, have been evaluated. Regarding water parameters, although some parameters exceed the optimal level, they have not influenced both the cultivation of trout and lettuce, since the system in general has remained in balance. It should be noted that in the tanks where the TM larvae have not been included, the growth of lettuce has been greater, but when the TM larvae have increased by $25 \%$, a significant improvement has been observed in the cultivation of trout, thus confirming the capacity of the TM larvae to replace the feed based on fish flour.

KEYWORDS: aquaponics, aquaculture, hydroponics, Tenebrio molitor, circular economy.

* Harremanetan jartzeko / Corresponding author: Ainara Saralegi. Ingeniaritza Kimikoa eta Ingurumenaren Ingeniaritza Departamentua, Vitoria-Gasteizko Ingeniaritza Eskola, Euskal Herriko Unibertsitatea (UPV/EHU). - ainara.saralegi@ehu.eus https://orcid.org/0000-0002-7583-9981.

Nola aipatu / How to cite: Arregi, Maite; Subinas, Beñat; Elissalt, Oier; Arrieta, Oihane; Oreja, Leire; Barriola, Maria Jose; Saralegi, Ainara (2021). «Landare eta arrainen ekoizpen jasangarrirako akuaponia sistema baten garapena Tenebrio molitor intsektuaren larbak erabiliz»; Ekaia, 39, 2021, 211-228. (https://doi.org/10.1387/ekaia.21850).

Jasoa: 2020, ekainak 30; Onartua: 2020, irailak 9.

ISSN 0214-9001 - elSSN 2444-3255 / (c) 2021 UPV/EHU

(c) (i) (2) Obra hau Creative Commons Atribución 4.0 Internacional-en

lizentziapean dago 
Maite Arregi, Beñat Subinas, Oier Elissalt, Oihane Arrieta, Leire Oreja, Maria Jose Barriola, Ainara Saralegi

\section{SARRERA}

XXI. mendeko erronketariko bat biztanleria guztia elikagaiz hornitzea da; izan ere, biztanleriaren hazkunde esponentziala dela eta, 2050. urtean mundua 9.000 miloi biztanle izatera helduko da [1]. Giza beharrizanak asetzeko, 'Food and Agriculture Organization' (FAO) erakundeak, 2050. urte bitartean elikagaien ekoizpena \% 70ean handitu beharko dela aurreikusten du [2]. Elikadura eskari hori asetzeko, akuikultura, hau da, uretako organismoen hazkuntza kontrolatua, paper garrantzitsu bat jokatzen ari da [1]. Izan ere, azken hamarkadan, elikagai gisa erabiltzen diren eta jatorri akuatikoa duten animalien erdia baino gehiago akuikulturatik dator, eta estimazioek diote 2030ean kopuru hori \% 65ekoa izango dela [2]. Hala ere, nabarmentzekoak dira akuikultura-ustiapenek sorrarazten dituzten ingurumen-inpaktuak, baliabide hidrikoen gehiegizko erabilera, isurien gehiegizko materia organiko kantitatea eta substantzia toxikoen presentzia, besteak beste $[3,4]$.

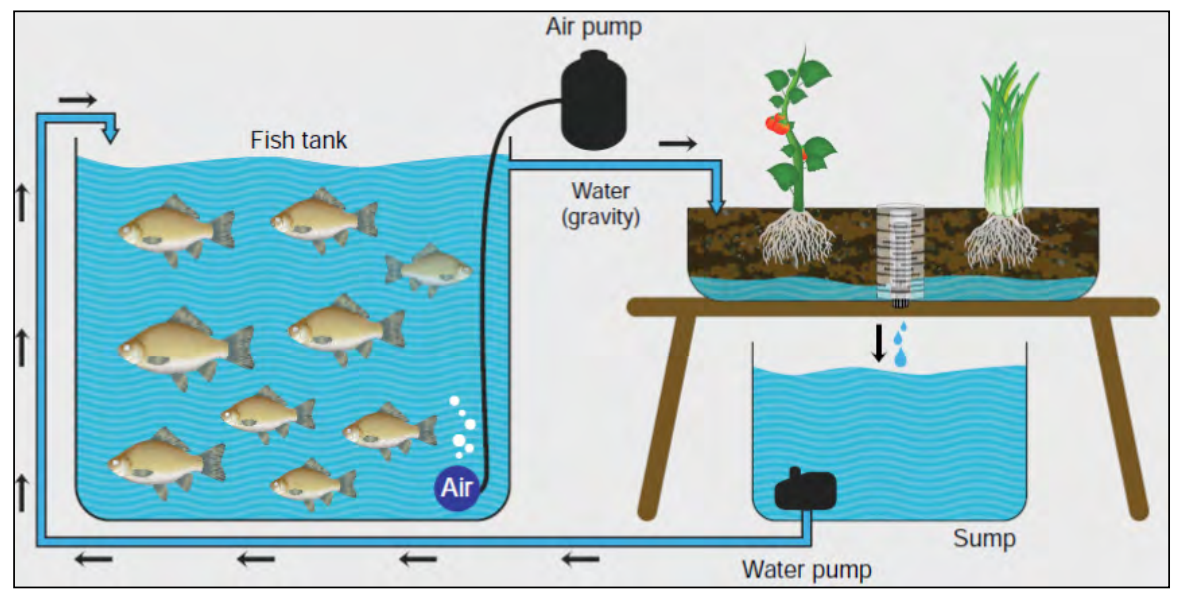

1. irudia. Akuaponia-sistema sinple baten diseinua [9].

Egoera horren aurrean, elikagaien eskasiari modu jasangarrian aurre egiteko eta Garapen Iraunkorrerako 2030 Agendarekin bat eginez [5], akuaponia aurkezten da (1. irudia), alegia, akuikulturaren eta hidroponiaren konbinaketa bidez osatzen den sistema, nutrizio-balio altuko arrain eta barazkiak uraren birzirkulazio-sistema itxi batean modu jasangarrian ekoiztea [3]. Hidroponia deritzo landareak mantenugaien iturri- eta sostengu-funtzioa duen lurrik gabe hazteari, landareak ur zein gatz mineralez osaturiko soluzio ezberdinez elikatuz [6]. Akuikultura, aldiz, gizakiaren beharrizanak asetzeko uretako organismoen hazkuntzan datza, hala nola, arrain, 
molusku, krustazeo zein landare ezberdinak [7]. Bi sistemak uztartuz, akuaponian, birzirkulazio-sistemaren bidez, arrainak aurkitzen diren tangetako ura filtro biologiko batetik pasatzen da sistema hidroponikora igaro aurretik, eta ondoren, berriro ere tangara bueltatzen da sistema itxia osatuz (ikusi 1. irudia) $[8,9]$.

Filtro biologikoetan, bakterio nitrifikatzaileek, arrainek hondakin metaboliko gisa iraitzitako amoniakoa $\left(\mathrm{NH}_{3}\right)$ metabolizatzen dute, nitrito $\left(\mathrm{NO}_{2}^{-}\right)$ moduan lehenengo eta nitrato $\left(\mathrm{NO}_{3}{ }^{-}\right)$moduan ondoren, landareentzat mantenugai bihurtuz [9]. Bestalde, ura filtro biologikoetatik pasatu eta gero, sistema hidroponikora doa, eta han landareek mantenugaiak xurgatzean ura purifikatzen dute, arrainentzat toxikoak diren substantzia nitrogenatuak ezabatuz [9]. Horretarako, akuaponia-sistemaren motorra diren ur- eta oxigeno-ponpak paper garrantzitsua jokatzen dute, haien bidez osatzen baita akuaponia-sistema osatzen duten izaki bizidunentzat beharrezkoa den birzirkulazio-sistema itxia [8].

Sistema itxi horren funtzionamendu egokiaren bidez, arrain eta barazkien ekoizpenean uraren kontsumoa \% 90ean murriztu daiteke, horrela bide batez produkzioaren errendimendua eta kostua jaitsiz. Bestalde, ongarrietan \% 45 ere aurreztu daiteke, eta, hidroponia hutsean ez bezala, ez dira soluzio nutritiboak behar landareentzat: izan ere, arrainek landareek behar dituzten 16 elementuetatik \% 80 ematen baitiete. Nahiz eta akuaponia-sistemako landarebolumenaren ekoizpena arrain kantitateak baldintzatu, jasota dago arrain tona bakoitzeko 7 tona labore ekoitz daitezkeela [3]. Hori guztia dela eta, akuaponia-sistema, urari, elikagaiei eta ingurumenari mesede egiten dien landare zein uretako organismoen ekoizpen-sistema gisa aurkezten da [3].

Jasangarritasunari dagokionez, ordea, akuaponiaren gabezia handienetariko bat itsas arrantzarekiko menpekotasuna da. Izan ere, sistema hauetan arrainak elikatzeko erabiltzen diren pentsuen funtsezko osagaiak arrain-irina eta arrain-olioa dira. Gainera, pentsu hauez gain, arrainak elikatzeko, kalitate baxuagoko arrainak ere erabiltzen dira [10]. Beraz, pentsu alternatiboak bilatzea da azken hamarkadako erronka, ekonomikoki errentagarriagoak izateaz gain, jasangarriagoak izateko, horrela akuaponia-sistemetan itsas arrantzarekiko menpekotasuna hautsiz [10,11].

Pentsu alternatiboen bilaketaren erronkaren aurrean, eta arrainen dietaren funtsean dagoen arrain-irinaren kalitate nutritibo nabarmenak ikusirik, osagai nutritibo antzekoak dituzten alternatibak bilatu dira. Horien artean aurkitzen dira jatorri zelulabakarreko irinak (onddo, bakterio, mikroalga edo legami jatorrikoak), irin begetalak (zereal alez, hala nola, artoa zein garia; lekalez, soia besteak beste; eta koltza hazi oleaginosoz osatuak), eta animalia jatorriko irinak (odol, hezur, luma eta oilasko soberakinetan oinarritutako irinak) [12]. Hala eta guztiz ere, irin hauek, ekonomikoki errentagarriak ez izateaz gain, hainbat desabantaila aurkezten dituzte: esaterako, 
Maite Arregi, Beñat Subinas, Oier Elissalt, Oihane Arrieta, Leire Oreja, Maria Jose Barriola, Ainara Saralegi

proteina kantitate txikiak, oinarrizko aminoazidoen eta oinarrizko ez direnen arteko desoreka, eta digerigarritasun-arazoak [12].

Azken hamarkadan, aldiz, intsektuen abantailez jabetuta, intsektu espezie ezberdinetatik eratorritako irinak agertu dira alternatibatzat: izan ere, arrain-irina ordezkatzen duen proteina-iturri izan daitezke. Proteinez gain, gantz-azidoetan, zuntzetan eta hainbat mikromantenugaitan aberatsak dira pentsu hauek, hala nola, kobre, burdin, magnesio, fosforo, manganeso, selenio eta zinkean [13]. Intsektuen hazkuntza modu ez-intentsibo batean emateko, ez da hasierako inbertsio handirik behar; izan ere, intsektuak ingurumenean aurkitzen dira, eta hazteko ez dute instalazio handirik behar, ezta ur-kontsumo handirik ere. Horrela, ekonomikoki zein ingurumenari dagokionez, alternatiba egokia izan daiteke intsektuetan oinarritutako pentsua. Gainera, animalientzako elikagai bihurtzeko ez dute prozesatze handirik behar. Irina lortzeko, eho egiten da, baina kasu honetan, arrainek osorik kontsumi dezakete; izan ere, intsektuak beren dieta naturalaren parte dira [13]. Aipatzekoa da, halaber, intsektuak, odol hotzeko animaliak izaki, elikagai bihurtzean oso eraginkorrak direla. Esaterako, $2 \mathrm{~kg}$ elikagairekin intsektuaren masa $1 \mathrm{~kg}$ handitzera hel daiteke, betiere espeziearen arabera [13]. Hau guztia kontuan izanik, garapen jasangarri baten eta ekonomia zirkular baten aldeko apustu garbia da intsektuetan oinarritutako pentsuak erabiltzea $[12,13]$.

«Federación Internacional de Industrias de Piensos»-en (IFIF) arabera, «irin horiko harra» (Tenebrio Molitor) intsektu espeziea, bertzeak bertze, larben bidez eskala handian pentsuak ekoizteko gai izateaz gain, egokia da hondakin organikoen biokonbertsiorako, hain zuzen ere, urteko $1.300 \mathrm{mi}-$ lioi tona hondakin organiko eralda baititzake. Gainera, bizi-ziklo laburra izateaz gain, elikagai-industrian jada aplikazioa dauka maskoten elikagai gisara, eta haren ustiapena ezagutzen da [13].

Honela bada, garapen jasangarria eta ekonomia zirkularra bultzatzeko asmoz, lan honen helburua, akuaponia-sisteman normalean erabiltzen diren arrain-irinean oinarritutako pentsuen alternatiba gisa TM intsektu espeziearen larbetan oinarrituko dietaren nutrizio-potentziala ebaluatzea da. Horretarako, ortzadar-amuarrain (Oncorhynchus mykiss) zein letxugez (Lactuca Sativa) osatutako akuaponia-sistema batean espezie hauen hazkundean pentsuak duen eragina aztertu da.

\section{ESPERIMENTUAREN DISEINUA}

\subsection{Akuaponia-sistemaren diseinua}

Lan honetan, akuaponia-sistema diseinatzeko orduan, arrainentzako 200 L-ko 9 beirazko tanga kokatu dira eta zoriz tanga bakoitzaren barruan 
10 ortzadar-amuarrain (Oncorhynchus mykiss) sartu dira. Tangaren dimentsioak arrainen biomasaren arabera aukeratu dira, hau da, tanga bakoitzeko arrain pisu totalaren, tamainaren zein espeziearen arabera $[14,15]$. Ur-tangen gainaldean, arrainak tangetatik ez ateratzeko, sareak ere jarri dira [9].

Sistema hidroponikorako, berriz, letxuga (Lactuca sativa) espeziea aukeratu da; izan ere, espezie hau negu-udaberriko laborea da, eta hazteko 24-31 egun behar ditu, planteatutako esperimentuaren periodora ezin hobeto egokituz. Letxuga espezieak barietate asko dituen arren, «haritz-hosto letxuga» izenez ezagututakoa aukeratu da, hosto kopuru txikiagoa duenez hazkuntza ebaluatzeko zailtasunak saihesteko. Honela, aurrez ereindako 216 letxuga, 5-8 hosto kopuru zituztelarik, sistema akuaponikora lekualdatu dira, tanga bakoitzari konektaturiko sistema hidroponikoan 24 letxuga (Lactuca sativa) «haritz-hosto» barietatekoak landatuz, betiere sistema akuaponikoak jasan dezakeen dentsitatea aintzat hartuta [9]. Horretarako, sustraietako lur guztia kendu eta sustraiak belaki batekin bildu dira ur-hornidura bermatzeko [16]. Haien arteko distantzia $18-30 \mathrm{~cm}$ ingurukoa izatea gomendatzen da, 20-25 buru/ $\mathrm{m}^{2}-k o$, hazteko behar adina leku izan dezaten [9].

Diseinatu den akuaponia-sistemako amuarrainen elikagai gisa, pentsu konbentzionala eta Insekt Label Biotech S.L enpresak hornitutako patogenorik gabeko TM intsektuaren larba izoztuak erabili dira. Horrela, TM intsektu espeziearen larba kantitate ezberdinak dituzten hiru dieta esperimental diseinatu dira. Lehen taldea, hau da, lehen hiru tangek osatzen dutena, kontrolak izango liratekeenak, pentsu konbentzionalarekin soilik elikatu da (TM0). Bertze bi taldeetan TM larbak gehitu dira proportzio ezberdinetan, \% 25 eta \% 50, TM25 eta TM50, hurrenez hurren [17]. Gainera, amuarrainak elikatzeko orduan, haien ahoaren tamaina eta elikadura-dosia ere kontuan hartu beharreko parametroak dira $[18,19]$. Horregatik, lan honetan, 2,5 mm-ko diametroko pentsu komertziala eta TM intsektu espeziearen larba txikituak erabili dira, eta eguneroko pentsu gramo kopuru totala 8-10 g-koa izan da [19]. Azkenik, aipatu behar da lan honetan erabili den pentsu konbentzionala bereziki tilapientzat erabilitako pentsua dela (momentuan pentsu mota hau lortzeko izandako eskuragarritasuna dela eta), proteinetan baxua eta arrain omniboroentzat diseinatua, eta ez amuarrainak bezalako arrain karniboroentzat. Ondorioz, faktore hau emaitzetan kontuan izan beharko da.

\subsection{Karakterizazio-teknikak}

\subsubsection{Parametro fisiko-kimikoak}

Uraren kalitateak berebiziko garrantzia du akuaponia-sistemaren funtzionamendu eta elikagaien ekoizpen egokian: izan ere, bakterioentzat, arrainentzat zein landareentzat bizirauteko beharrezkoak diren mantenu- 
Maite Arregi, Beñat Subinas, Oier Elissalt, Oihane Arrieta, Leire Oreja, Maria Jose Barriola, Ainara Saralegi

gaiak uraren bidez garraiatzen dira. Horregatik, uraren kalitatea zehazteko hainbat parametro fisiko-kimiko kontuan hartu behar dira: hala nola, tenperatura, disolbatutako oxigenoa, $\mathrm{pHa}$, eroankortasun elektrikoa eta konposatu nitrogenatuak. Akuaponia-sisteman parte hartzen duten 3 organismoek uraren kalitatearekiko tolerantzia espezifikoa dute (ikusi 1. taula). Hori dela eta, nahiz eta organismo bakoitza bere maila optimoan ez egon, hiruen arteko oreka aurkitzean datza akuaponia-sistema baten funtzionamendu egokiaren gakoa [9].

1. taula. Ur hotzetako arrainen, landare hidroponikoen, bakterioen eta akuaponia-sistemen tolerantzia orokorrak uraren parametro fisiko-kimikoekiko: tenperatura (T); $\mathrm{pHa} ; \mathrm{NH}_{3}$ kontzentrazioa; $\mathrm{NO}_{2}{ }^{-}$kontzentrazioa; $\mathrm{NO}_{3}{ }^{-}$kontzentrazioa; eta disolbatutako oxigeno kontzentrazioa (DO) [9].

\begin{tabular}{lcccccc}
\hline \multicolumn{1}{c}{ Organismoak } & $\mathrm{T}\left({ }^{\circ} \mathrm{C}\right)$ & \multicolumn{1}{c}{$\mathrm{pH}$} & $\mathrm{NH}_{3}(\mathrm{mg} / \mathrm{L})$ & $\mathrm{NO}_{2}^{-}(\mathrm{mg} / \mathrm{L})$ & $\mathrm{NO}_{3}{ }^{-}(\mathrm{mg} / \mathrm{L})$ & $\mathrm{DO}(\mathrm{mg} / \mathrm{L})$ \\
\hline Ur hotzetako arrainak & $10-18$ & $6-8,5$ & $<1$ & $<0,1$ & $<400$ & $6-8$ \\
Landareak & $16-30$ & $5,5-7,5$ & $<30$ & $<1$ & - & $>3$ \\
Bakterioak & $14-34$ & $6-8,5$ & $<3$ & $<1$ & - & $4-8$ \\
Akuaponia-sistemak & $18-30$ & $6-7$ & $<1$ & $<1$ & $5-150$ & $5-8$ \\
\hline
\end{tabular}

Tanga bakoitzeko uraren kalitatearen ebaluazioa ProfiLux-en bidez gauzatu da 46 egunez, ProfiLux 3.1T modeloaren bidez [20], hain zuzen ere, $\mathrm{pHa}$, uraren tenperatura, eroankortasun elektriko zein oxigenoaren disolbagarritasuna neurtzen dituen zundez baliatuz. Datu-bilketa, asteko 5 egunetan egin da, arrainak elikatu baino lehen: izan ere, datuak arrainak elikatu berritan hartuz gero emaitzak ez lirateke adierazgarriak izango. Uraren tenperatura neurtzerako orduan, tanga batekoa soilik neurtu da, tanga guztietan tenperatura antzekoa dela aintzat hartu baita, tanga guztiak gela berean daudelako. Aipatzekoa da disolbatutako oxigenoaren kontzentrazioari eta eroankortasun elektrikoari dagozkion datuak ez direla lan honetan aurkezten, uneoro balioak egokiak direla bermatu baita eta ez baita aldaketa esanguratsurik ikusi.

Nitrogeno konposatuen $\left(\mathrm{NH}_{3}, \mathrm{NO}_{2}^{-}\right.$eta $\left.\mathrm{NO}_{3}^{-}\right)$neurketa gauzatzeko, aldiz, HI 83200 modeloko Hanna fotometroa erabili da. Fotometro horren bidez, tanga bakoitzetik $10 \mathrm{~mL}$-ko laginak hartuz, tanga bakoitzeko nitrogeno konposatuen kontzentrazioa kalkulatu da. Horretarako, lagin bakoitzetik azpilaginak hartu dira eta erreaktibo ezberdinak gehitu zaizkie $\left(\mathrm{NH}_{3}-\right.$ ren kasurako HI93700-A eta HI93700-B, $\mathrm{NO}_{2}^{-}$-ren kasurako HI93707-0 eta $\mathrm{NO}_{3}{ }^{-}$-ren kasurako HI93728-0; erreaktibo guztiak «Suministro urgente al laboratorio (SUL)» enpresak hornitu ditu); kasu bakoitzean gertatzen den erreakzioaren ondoren, fotometroaren bidez detekta daitezkeen konposatuak eratzen dira, $\mathrm{NH}_{3}, \mathrm{NO}_{2}{ }^{-}$eta $\mathrm{NO}_{3}{ }^{-}$konposatuen kontzentrazioa neurtzea 
ahalbidetuz. Esperimentuaren hasieran asteko 5 egunetan burutu dira neurketak, baina Covid-19-a dela eta, amaieran, maiztasun gutxiagorekin egin dira neurketak, betiere gutxienez astean behin konposatu nitrogenatuen kontzentrazioa kontrolatuz, akuaponia-sistema orekan dagoela bermatzeko [9].

\subsubsection{Landare zein arrainen ebaluazioa}

Letxugen hazkundea ebaluatzeko, astero (27. egunera arte, Covid-19-a dela eta ezin izan baitira neurketa gehiago egin) haien hosto kopurua eta hosto luzeenaren luzera (mm-tan) neurtu dira metro baten laguntzarekin. Horrez gain, usteldutako hosto kopurua ere aintzat hartu da. Izan ere, mantenugai eskasiak edota akuaponia-sistema baldintza optimoetan ez egoteak, landareak estres egoera pairatzea eragiten du, landarearen zein sustraien hazkuntza urritasuna emanez, edota hostoak ustelduz. Astero egindako kontrolaren zein monitorizazioaren bidez, plaga ezberdinen kontrola ere egin da [9]. Egindako neurketetan oinarrituz, letxugen hazkuntza-tasa (LHT) (1. formula) zein hazkuntza-tasa espezifikoa (LHTe) (2. formula) kalkulatu dira [21],

$$
\begin{gathered}
\text { LHT }\left(\frac{\mathrm{cm}}{\text { egun }}\right)=\frac{\mathrm{BL}-\mathrm{HL}}{\mathrm{BE}-\mathrm{HE}} \\
\operatorname{LHTe}\left(\frac{\%}{\text { egun }}\right)=\frac{\ln (\mathrm{BL})-\ln (\mathrm{HL})}{\mathrm{BE}-\mathrm{HE}} \times 100
\end{gathered}
$$

non BL eta HL bukaerako eta hasierako luzerak diren, hurrenez hurren, cm-tan neurtuta, eta BE eta HE bukaerako eta hasierako egunak diren, hurrenez hurren.

Arrainen hazkuntza aztertzeko, esperimentua hasi aurretik SBS-LW500/10 modeloko balantza digitala erabiliz tanga bakoitzeko amuarrainen biomasa kalkulatu da. Hamarnaka pisatzeaz gain, tanga bakoitzetik zoriz ale bat hartu da, ale bakarraren pisua ere jasoz. Esperimentuak aurrera egin ahala, elikatzeko orduan arrainen jokabidea eta aspektua aztertu dira. Izan ere, uraren kalitate desegokiek edota parasito, onddo edo birus patogenoek, arrainek estresa pairatzea eragiten dute. Hori dela eta, uraren gainazalean arnasestuka dauden, edo hegatsak, brankiak eta begiak gorrixkak dituzten aztertu da [9]. Estres-egoerak eragindako heriotza kopuruak ere jaso dira [14]. Hilabete baten buruan amuarrainak berriz ere pisatu dira, hazkuntza-parametro ezberdinak kalkulatu ahal izateko. Irabazitako pisua (IP) (3. formula) honako adierazpen matematiko hau erabiliz kalkulatu da [17],

$$
\mathrm{IP}(\mathrm{g})=\mathrm{BP}-\mathrm{HP}
$$

non BP eta HP bukaerako eta hasierako pisuak diren, hurrenez hurren, gramotan adierazita. 
Maite Arregi, Beñat Subinas, Oier Elissalt, Oihane Arrieta, Leire Oreja, Maria Jose Barriola, Ainara Saralegi

Ortzadar-amuarrainen hazkuntza-tasa espezifikoa (AHTe) (4. formula), elikagai-bihurketaren faktorea (EBF) (5. formula) eta biziraupen-tasa (BT) (6. formula), berriz, honako adierazpen matematiko hauek erabiliz kalkulatu dira $[17,22]$,

$$
\begin{aligned}
& \operatorname{AHTe}\left(\frac{\%}{\text { egun }}\right)=\frac{\ln (\mathrm{BP})-\ln (\mathrm{HP})}{\mathrm{BE}-\mathrm{HE}} \times 100 \\
& \mathrm{EBF}=\frac{\mathrm{KE}}{\mathrm{IP}} \\
& \mathrm{BT}(\%)=(\mathrm{BI}-\mathrm{HI}) \times 100
\end{aligned}
$$

non KE kontsumitutako elikagai kopurua den, gramotan adierazita, eta BI eta HI, bukaerako eta hasierako ortzadar-amuarrain banakoen kopurua diren, hurrenez hurren.

\section{EMAITZAK ETA EZTABAIDA}

\subsection{Uraren kalitatearen ebaluazioa}

Uraren tenperaturaren balioei erreparatuz gero, gehienak 12 eta $18{ }^{\circ} \mathrm{C}$ bitartean ibili dira, nahiz eta esperimentuaren amaierako egunetan tenperaturak $18{ }^{\circ} \mathrm{C}$-ko balioak gainditu dituen (ikusi 2. irudia). Amuarrainentzat, ur hotzetako espeziea izanik, $18{ }^{\circ} \mathrm{C}$-tik gorako balioak beroegiak dira [9], eta hauen hazkuntza-prozesuan eta patogenoekiko erresistentzian eragiten dute [22]. Izan ere, tenperatura altuetan, oxigenoaren disolbagarritasun-maila txikiagoa da [9], eta amuarrainak gaixotasun zein parasitoen aurrean zaurgarriagoak bihurtzen dira edota hipoxia egoera batera heltzen dira, heriotza eraginez [23]. Kasu honetan, tenperatura altuak aireztagailuaren bidez balio optimoetara jaitsi direnez, ez da inolako heriotzarik izan.

Letxuga eta haien antzeko espezieentzat, aldiz, esperimentuan zehar neurtu diren tenperaturak egokiak dira, beste barazkiekin alderatuta tenperatura freskoak nahiago baitituzte, hala nola $26{ }^{\circ} \mathrm{C}$ baino baxuagoak. Izan ere, tenperatura altuetan, letxugek kaltzioa xurgatzeko duten gaitasuna galtzen dute, eta hazkuntza-prozesuan eragiten du honek [9]. Bakterioei dagokienez, ordea, tenperaturarekiko tolerantzia tarte handiagoa dute, 14-34 ${ }^{\circ} \mathrm{C}$ bitartekoa, alegia (1. taula). Esperimentuaren 25. eta 27. egunetan, $12{ }^{\circ} \mathrm{C}$-ko balioak neurtu dira (ikusi 2. irudia), zeinak bakterioen produktibitatean eragin baitezakete, $10^{\circ} \mathrm{C}$-tik behera bakterioen produktibitatea \% 50era jaitsi baitaiteke [9]. Hala ere, momentu jakinetan besterik ez dira mugaz kanpoko tenperaturak neurtu; beraz, oro har, tenperaturaren aldetik akuaponia-sistemaren oreka baieztatu da. 
Landare eta arrainen ekoizpen jasangarrirako akuaponia sistema baten garapena Tenebrio molitor intsektuaren larbak erabiliz

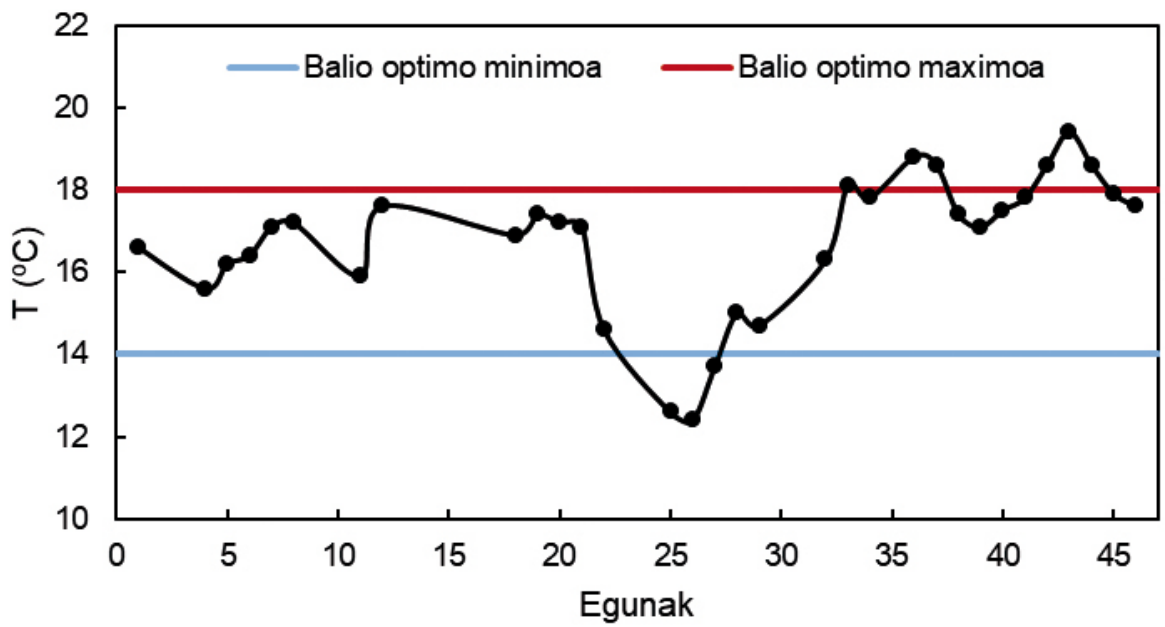

2. irudia. Akuaponia tangetako uraren tenperaturaren eboluzioa.

pHari dagokionez, lehenengo egunetan 7,5 eta 8 arteko balioak neurtu dira, hurrengo egunetako balioekin alderatuta balio altuagoak (ikusi 3. irudia). Behin akuaponia-sistema abian jartzean, biofiltroen funtzionamendua dela eta, nitrifikazio-prozesua gertatzen da, eta akuaponia-sistemako pHa murrizten da. Bakterio nitrifikatzaileek, hidroxilo ioiak $\left(\mathrm{OH}^{-}\right)$kontsumitzeaz gain, amoniakoa nitrato bihurtzean hidrogeno protoiak $\left(\mathrm{H}^{+}\right)$ askatzen dituzte. Horrez gain, arrainek, arnasketa-prozesua dela eta, karbono dioxidoa askatzen dute, eta hori urarekin kontaktuan jartzean azido karboniko $\left(\mathrm{H}_{2} \mathrm{CO}_{3}\right)$ bihurtzen da. Ondorioz, bakterio nitrikifatzaileen jarduera eta arrainen arnasketa direla eta, pHaren balioa murriztu egiten da denborarekin, azidotu alegia, oreka bat lortu arte [9]. Behin oreka hori lortzen denean, pHaren balioak 6 eta 7,5 balioen artean mantentzen dira (ikusi 3. irudia), akuaponia-sistema osatzen duten organismoentzat $\mathrm{pH}$ optimoa 6-7 ingurukoa delarik [9].

Konposatu nitrogenatuen kontzentrazioei erreparatuz gero, lehenengo asteak igaro ondoren, $\mathrm{NH}_{3}$ zein $\mathrm{NO}_{2}^{-}$konposatuen kasuan kontzentrazioak egonkortu egin dira (ikusi 4. irudia). Akuaponia-sistema batean, $\mathrm{NH}_{3}$ zein $\mathrm{NO}_{2}^{-}$kontzentrazioek 0-1 mg/L balioen artean egon behar dute oreka bermatzeko (1. taula). Amoniakoren kasuan, egun jakin batzuetan balio maximoa gainditu egin da (ikusi 4a., 4b. eta 4c. irudiak), $1 \mathrm{mg} / \mathrm{L}$ balioak gainditzeak arrainen nerbio-sisteman eragin dezakeelarik, arnas estua, zakatzen gorridura zein hauntura, gorputzean marra gorriak, edota heriotza eraginez. Aipatzekoa da $\mathrm{NH}_{3}$ kontzentrazioa pHaren araberako dela, besteak beste, $\mathrm{pH}$ baxuetan amonio ioi $\left(\mathrm{NH}_{4}{ }^{+}\right)$moduan aurkitzen baita amoniakoa eta $\mathrm{pH}$ altuetan $\mathrm{NH}_{3}$ moduan. Ondorioz, 25. egunetik aurrera, behin pHaren balioak 
Maite Arregi, Beñat Subinas, Oier Elissalt, Oihane Arrieta, Leire Oreja, Maria Jose Barriola, Ainara Saralegi

egonkortu eta 7 inguruan geratu direnean, $\mathrm{NH}_{3}$ konposatuaren kontzentrazioak ere egonkortu egin dira, eta ez dira $1 \mathrm{mg} / \mathrm{L}$-ko balioak gainditu.
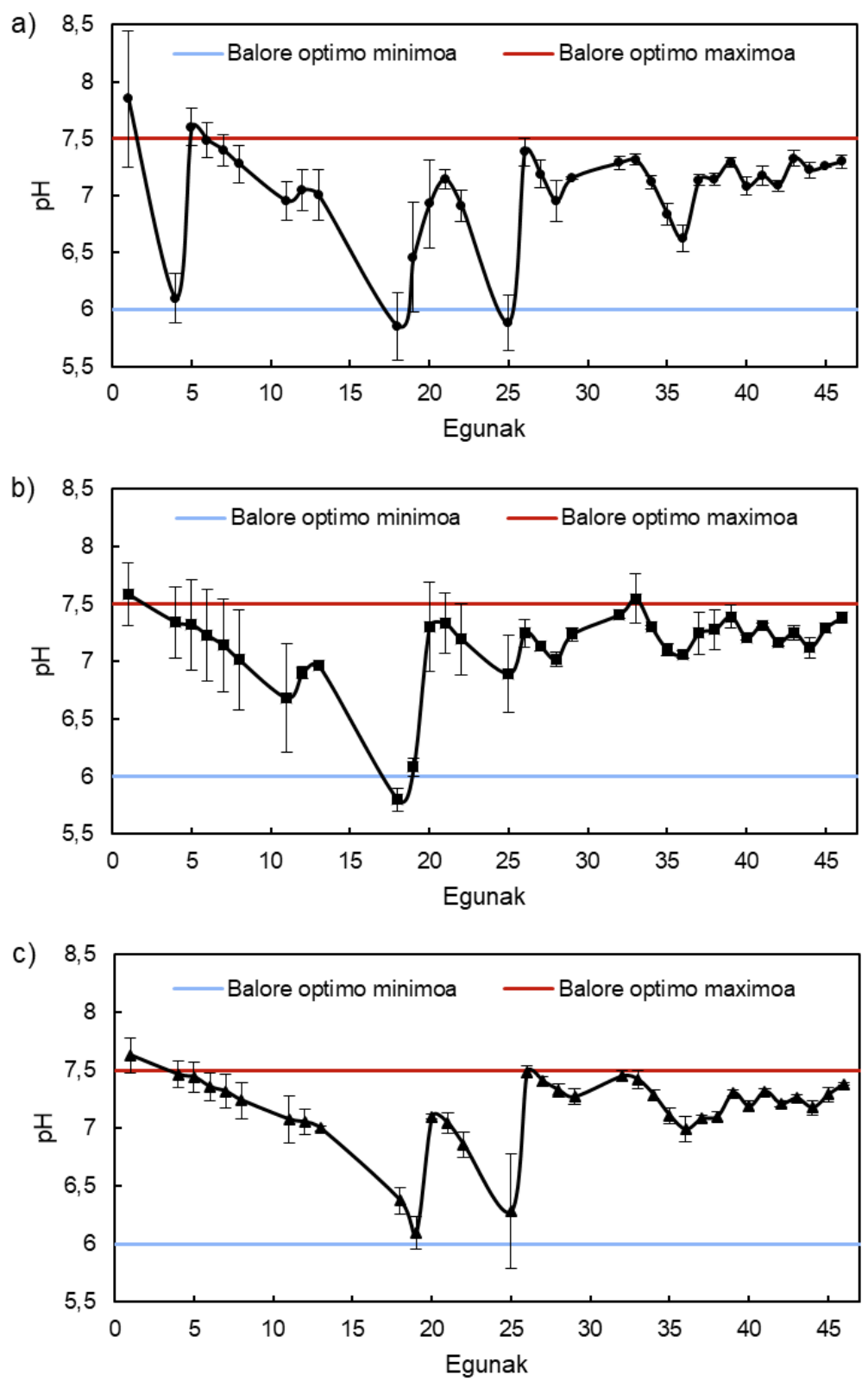

3. irudia. Akuaponia-tangetako pHaren balioak, a) TM0 sistemarentzat, b) TM25 sistemarentzat eta c) TM50 sistemarentzat. 

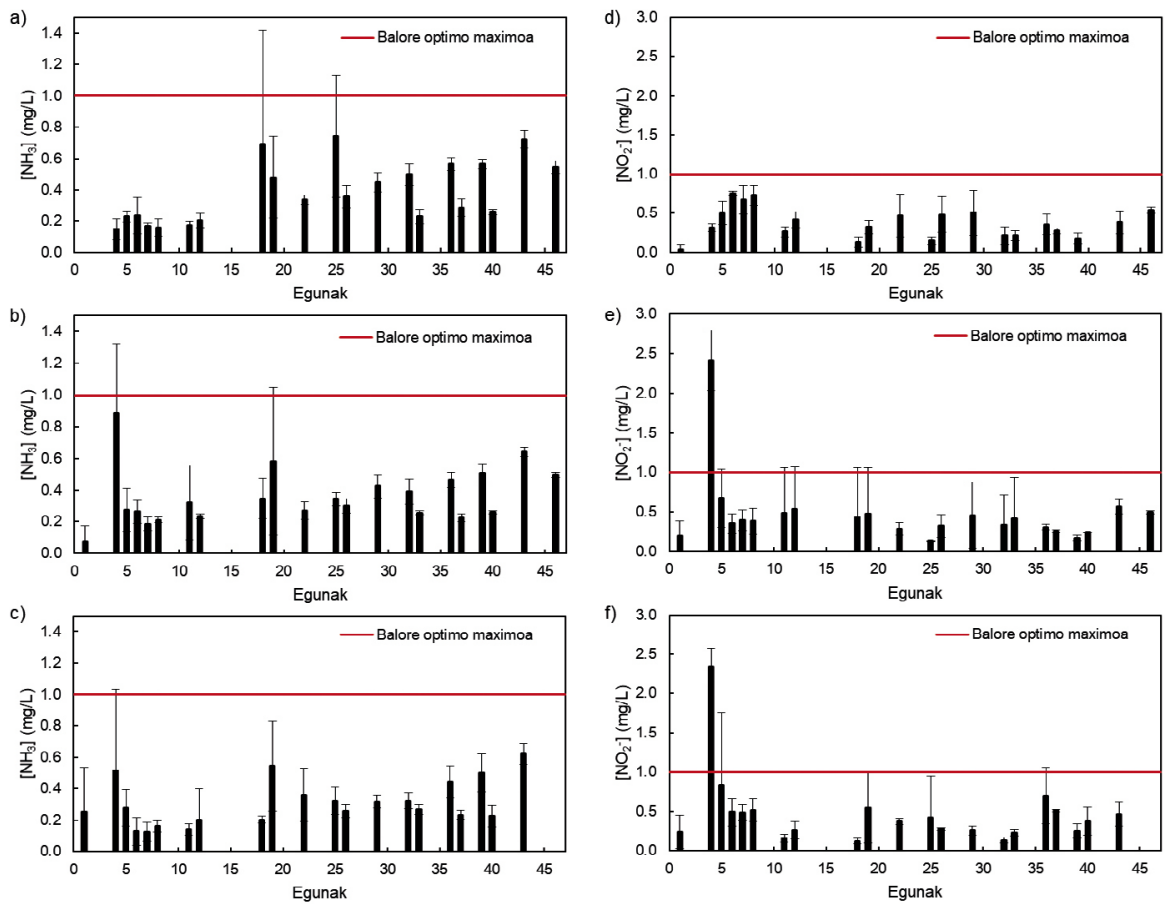

4. irudia. Akuaponia-tangetako $\mathrm{NH}_{3}\left(\mathrm{a}, \mathrm{b}\right.$, eta c) eta $\mathrm{NO}_{2}^{-}$(d, e, eta f) konposatuen kontzentrazioak, a) eta d) TM0 sistemarentzat, b) eta e) TM25 sistemarentzat eta c) eta f) TM50 sistemarentzat.

Akuaponia-tangetako $\mathrm{NO}_{2}{ }^{-}$kontzentrazioei dagokienez (ikusi 4d., 4e. eta 4f. irudiak), TM25 eta TM50 dieta jaso duten tangetan, lehen egunetan, toxikotasun-maila altuak $\left(\mathrm{NO}_{2}{ }^{-}\right.$kontzentrazio altuak) neurtu dira, hala nola $2 \mathrm{mg} /$ L-ko kontzentrazioak gaindituz. $\mathrm{NO}_{2}{ }^{-}$maila altu horiek oxigenoa amuarrainen odol hodietatik ez pasatzea eragin dezakete, odolak marroi kolorea hartuz eta arrainak gainazalean arnasestuka hasiz. Datu hauen arabera, badirudi TM25 eta TM50 dieta jaso duten tangetan akuaponia-sistemaren oreka lortzea gehiago kostatu dela. Hala ere, amoniako kontzentrazioarekin ikusi den moduan, lehen asteak igaro ondoren oreka lortu da, eta hortik aurrera $\mathrm{NO}_{2}{ }^{-}$kontzentrazioak batez beste balio optimo maximoaren azpitik geratu dira.

Azkenik, $\mathrm{NO}_{3}{ }^{-}$konposatuaren kontzentrazioari dagokionez, akuaponiasistema batean optimoena, $\mathrm{NO}_{3}{ }^{-}$konposatuaren kontzentrazioa $5-150 \mathrm{mg} / \mathrm{L}$ artean mantentzea da, nahiz eta arrainek $300 \mathrm{mg} / \mathrm{L}-\mathrm{ko}$ balioak ere onar ditzaketen. 5. irudian ikus daitekeen moduan, esperimentuaren azken bi asteetan, $\mathrm{NO}_{3}{ }^{-}$konposatuaren kontzentrazioak $150 \mathrm{mg} / \mathrm{L}-\mathrm{ko}$ balioak gainditu ditu, eta gainera, azken egunetan, arrainek onar ditzaketen balioak ere 
Maite Arregi, Beñat Subinas, Oier Elissalt, Oihane Arrieta, Leire Oreja, Maria Jose Barriola, Ainara Saralegi

gainditu dira. Azken egunetan neurtu diren tenperatura altuak direla eta (2. irudia), oxigenoaren disolbagarritasuna handiagoa da, eta nitrifikazioa prozesu oxidatiboa denez (oxigenoaren presentzian gertatzen da), errazago gertatzen da, $\mathrm{NO}_{3}{ }^{-}$kontzentrazioa igoz [9]. Ondorioz, letxugetan gehiegizko hazkuntza izan daiteke, nitratoa hostoetan metatuz eta horrela giza osasuna kaltetuz. Beraz, esperimentuaren azken egunetan akuaponia-sistemaren oreka galdu dela ondorioztatu da, eta sistema berriro orekan jartzeak bere denbora behar duenez, ura ere aldatu behar baita, esperimentua 46. egunean amaitutzat eman da.
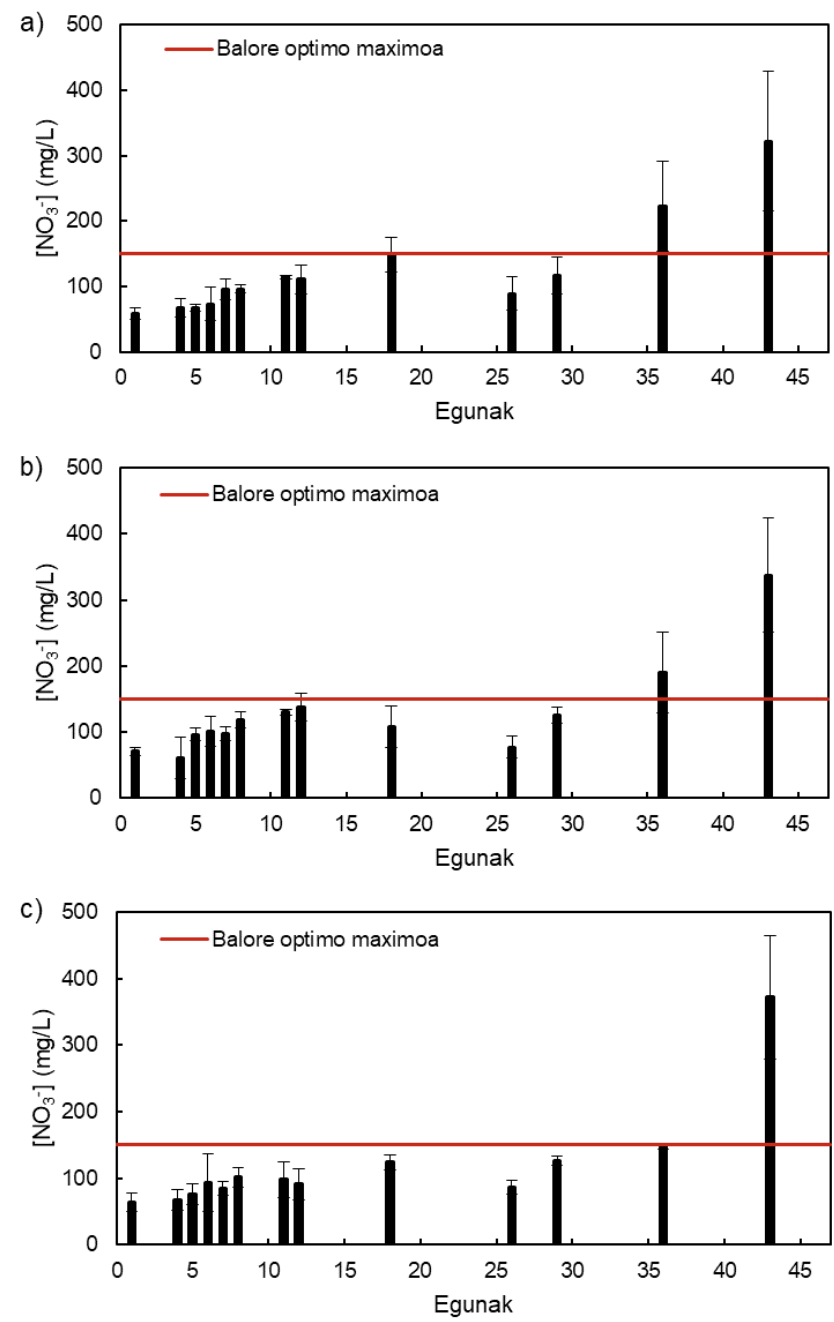

5. irudia. Akuaponia-tangetako $\mathrm{NO}_{3}^{-}$kontzentrazioak, a) TM0 sistemarentzat, b) TM25 sistemarentzat eta c) TM50 sistemarentzat. 


\subsection{Letxugen hazkuntzaren ebaluazioa}

Letxugen hazkuntza aztertzeko, hosto kopurua zein hosto luzeenaren luzera aztertu dira, horrela LHT eta LHTe balioak kalkulatuz (1. eta 2. formulak erabiliz). Hosto luzeenaren luzerari dagokionez, lehen bi asteetan, tanga guztietan hazkuntza gorakorra izan da, LHT eta LHTe balio altuagoak lortuz TM25 zein TM50 dieta jaso duten sistemetan (ikusi 2. taula). Hirugarren astean, ordea (13-20 egunak), hazkuntza gelditu egin da, bereziki TM larbez elikatutako tangetan (TM25 eta TM50 sistemak). Hala ere, 4. astean hazkuntza berreskuratu egin da, TM25 eta TM50 sistemetan berreskuratze nabarmenagoa lortu delarik (ikusi 2. taula). Izandako hazkuntzen emaitzak bibliografiako datuekin alderatuz, Caceres (2013) [16], LHT eta LHTe balio baxuagoak lortu dira lan honetan. Lan honetan erabili den pentsu konbentzionala amuarrainentzat egokia izan beharrean tilapientzat egokiagoa delako izan daiteke, amuarrainentzat mantenugai-proportzio desegokiak izanik, eta ondorioz letxugen hazkuntzan eraginez. Hala ere, hosto kopuruaren datuak aztertuz gero (6. irudia), denborarekin hosto kopuruaren gehikuntza bat gertatu dela ikus daiteke; beraz, letxugen hazkuntza bat gertatu, gertatu da.

2. taula. Akuaponia sistemetako letxugen hazkuntza parametroak jasotako dietaren arabera: LHT eta LHTe.

\begin{tabular}{c|cc|cc|cc}
\hline & \multicolumn{2}{|c|}{ TM0 } & \multicolumn{2}{c|}{ TM25 } & \multicolumn{2}{c}{ TM50 } \\
\hline Egunak & $\begin{array}{c}\text { LHT } \\
\text { (cm/egun) }\end{array}$ & $\begin{array}{c}\text { LHTe } \\
\text { (\%/egun) }\end{array}$ & $\begin{array}{c}\text { LHT } \\
\text { (cm/egun) }\end{array}$ & $\begin{array}{c}\text { LHTe } \\
\text { (\%/egun) }\end{array}$ & $\begin{array}{c}\text { LHT } \\
\text { (cm/egun) }\end{array}$ & $\begin{array}{c}\text { LHTe } \\
\text { (\%/egun) }\end{array}$ \\
\hline $1-6$ & $0,21 \pm 0,04$ & $2,45 \pm 0,49$ & $0,18 \pm 0,07$ & $2,67 \pm 0,65$ & $0,24 \pm 0,04$ & $2,69 \pm 0,41$ \\
$6-13$ & $0,22 \pm 0,12$ & $2,16 \pm 1,13$ & $0,27 \pm 0,11$ & $2,25 \pm 0,79$ & $0,21 \pm 0,03$ & $2,09 \pm 0,32$ \\
$13-20$ & $0,14 \pm 0,10$ & $1,24 \pm 0,88$ & $0,04 \pm 0,04$ & $0,33 \pm 0,37$ & $0,07 \pm 0,02$ & $0,60 \pm 0,21$ \\
$20-27$ & $0,18 \pm 0,04$ & $1,44 \pm 0,29$ & $0,19 \pm 0,04$ & $1,19 \pm 0,42$ & $0,20 \pm 0,05$ & $1,63 \pm 0,41$ \\
\hline TOTALA & $0,19 \pm 0,02$ & $1,78 \pm 0,18$ & $0,17 \pm 0,01$ & $1,62 \pm 0,09$ & $0,18 \pm 0,01$ & $1,68 \pm 0,11$ \\
\hline
\end{tabular}

Nahiz eta esperimentuaren hasieran TM0 sistemako letxugen hosto kopuruaren batezbestekoa bertze sistemetako letxugekin alderatuz baxuago izan, sistema honetan hosto kopuruan hazkuntza handiago izan da, hori bertze dieten gabeziengatik izan daitekeelarik (ikusi 6. irudia). Hostoen luzeraren hazkuntzan ez bezala, bertze ikerketetan lortutako emaitzekin alderatuta, lan honetan lortu den hosto kopuruaren hazkuntza nabarmentzekoa da: erabili den letxugen barietateagatik izan daiteke hori [16].

Oro har, hosto luzeenaren eta hosto kopuruaren hazkuntza aintzat hartuta, TM0 sistemarentzat datu hobeak lortu dira (2. taula eta 6. irudia). Izan 
Maite Arregi, Beñat Subinas, Oier Elissalt, Oihane Arrieta, Leire Oreja, Maria Jose Barriola, Ainara Saralegi

ere, pentsu konbentzionala nitrogeno zein fosforoan aberatsagoa da, hauek hostoen hazkuntzarako konposatu garrantzitsuak direlarik. Gainera, arrainek dietaren \% 30 aprobetxatzen dute, gainerakoa iraitzi egiten baitute, eta landareek hazkuntzarako mantenugai gisa aprobetxatu dezakete [21].

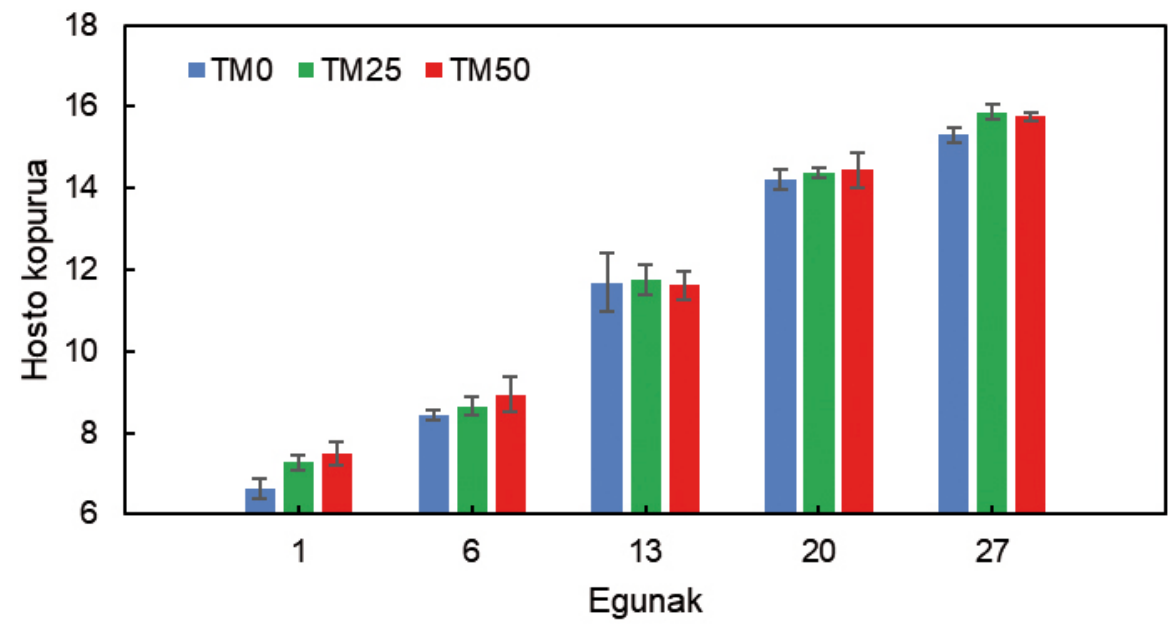

6. irudia. Akuaponia-sistemako letxugen hosto kopurua.

\subsection{Amuarrainen hazkuntzaren ebaluazioa}

Akuaponia sistemetako ortzadar-amuarrainen hazkuntza aztertzeko, amuarrainek dieta ezberdinak ongi onartu dituztela kontuan hartuta, parametro ezberdinen emaitzak jaso dira (ikusi 3. taula). Sistema akuaponikoetan arrainen hazkuntza eta elikagai bihurketa faktoreak, azterturiko uraren kalitatearen araberakoa izateaz gain, dietaren kalitatearen zein kantitatearen araberakoak dira [24]. Beraz, lan honetan, amuarrainen hazkuntzan gehienbat erabilitako dieta ezberdinek eragingo dute, kantitatea berdina izan baita eta uraren kalitateak antzeko joerak erakutsi baititu sistema gehienetan.

3. taula. Akuaponia-sistemako ortzadar-amuarrainen hazkuntza parametroak: HP, BP, IP, AHTe, EBF eta BT.

\begin{tabular}{lcccccc}
\hline Sistema & HP $(\mathrm{g})$ & BP $(\mathrm{g})$ & IP $(\mathrm{g})$ & AHTe (\%/egun) & \multicolumn{1}{c}{ EBF } & BT (\%) \\
\hline TM0 & $39,4 \pm 1,9$ & $72,0 \pm 4,9$ & $32,6 \pm 3,3$ & $2,0 \pm 0,1$ & $9,1 \pm 0,6$ & 100 \\
TM25 & $36,9 \pm 3,1$ & $74,8 \pm 20,3$ & $37,9 \pm 19,1$ & $2,3 \pm 0,8$ & $8,4 \pm 3,2$ & 100 \\
TM50 & $37,1 \pm 0,1$ & $59,8 \pm 1,8$ & $22,7 \pm 1,8$ & $1,6 \pm 0,1$ & $12,3 \pm 1,0$ & 100 \\
\hline
\end{tabular}


BT balioei dagokionez, kasu guztietan \% 100eko balioak lortu dira, amuarrain guztiek biziraun baitute esperimentuak iraun duen bitartean. Woynarovich et al. (2011)-ren arabera [14], akuaponia-sistema bateko 25 g-z gaindiko ortzadar-amuarrainen hilkortasun-tasa \% 5ekoa da 4-6 hilabeteko produkzio-periodoan. Beraz, nahiz eta kasu honetan hilabeteko iraupena duen esperimentua izan, BT balio guztiak \% 100ekoak izateak akuaponia-sistemaren funtzionamendu egokiaren seinale dira. Izan ere, nahiz eta uraren kalitatea aztertzeko orduan parametro batzuk maila optimoa gainditu, ez dute amuarrainen heriotzarik eragin.

HP eta BP balioei erreparatuz gero, TM25 dietaz elikatutako sistemetan HP balioak baxuagoak izanda ere, BP baliorik altuenak sistema horrentzat lortu dira (3. taula). Hori dela eta, TM25 sistemarentzat lortu dira AHTe balio altuenak, \% 2,3koak, hain zuzen. Hala eta guztiz ere, datuen desbideratzeak aztertuz, TM25 dietarekin elikatu diren sistemetan datuen desbideratze altuagoak lortu dira, eta tanga bakar bateko arrainen hazkuntza (6. tangakoak) batezbesteko orokorretik aldendu da. Aipatzeko da TM50 dietarekin elikatu diren amuarrainen kasuan IP eta AHTe balio baxuenak lortu direla. Egoera hori dietarekin erlazionatutako mantenugai ezberdinen eskasiagatik izan daiteke; ez, ordea, ahoratzea murritzagoa izan delako; izan ere, TM50 sistemako amuarrainek, besteek bezala, elikagaia ongi onartu dute.

EBF balioei dagokienez, balio baxuenak TM25 dietarekin elikatutako sistemarentzat lortu dira; balio altuenak, berriz, TM50 sistemarentzat (3. taula). Hala ere, normalean EBF balioak 2-3 artean egoten dira, kalitate oneko pentsuekin 0.6-1 bitarteko balioak ere lor daitezkeelarik, hau da, kalitate hobeko pentsuek EBF balio txikiagoak aurkezten dituzte [14]. TM25 dietarekin elikatu diren sistemen EBF balioak balio optimoetatik aldentzen diren arren, pentsu konbentzionalarekin elikatutako sistemetan baino datu hobeak lortu dira. Hain zuzen ere, pentsu konbentzionala egokia da tilapientzat, proteina kantitate baxuak baititu, baina amuarrainentzat proteina kantitate handiagoko pentsuak behar dira. Proteina-iturri hori TM larbek eman dezakete, proteinetan aberatsak baitira, elikaduraren zein bizi-fasearen arabera, kasu honetan erabili direnak \% 49,1eko proteina kopurua dutelarik [25].

TM larben abantailez jabetuta eta TM25 dietarekin elikaturiko amuarrainen EBF balioak zein hazkuntzari dagozkion emaitzak positiboenak izanda ere, TM50 dietaren bidez elikaturiko amuarrainen emaitzak ez dira hain onak izan (3. taula). Hori dela eta, pentsu konbentzionala TM intsektu espeziearen larbez gehiegizko kantitatean ordezkatzeak ekar ditzakeen kalteak agerian geratu dira. $\mathrm{Ng}$ et al. (2001) [26] ikerketaren emaitzetan ere, bagre afrikarretan hazkuntza errendimenduaren murrizpen bat gertatu da TM gehikuntza \% 40ko balioak gainditzean. Izan ere, TM larbek proteina kantitate handiak baldin badituzte ere, horien diges- 
Maite Arregi, Beñat Subinas, Oier Elissalt, Oihane Arrieta, Leire Oreja, Maria Jose Barriola, Ainara Saralegi

tio-arazoek zein oinarrizko aminoazidoen artean duten desorekak amuarrainen hazkuntza inhibi dezakete [12]. Hala ere, amuarrainaren garapenaren lehen fasean intsektuen bidez elikatzeak eragindako hazkuntza eza ez da itzulezina. De Haro (2015) ikerketaren emaitzen arabera [12], lehen fasean TM eta gero pentsu konbentzionalarekin elikatutako arrainek, bizitzako fase guztietan pentsu konbentzionalarekin elikaturiko arrainen hazkuntza bera izan dutela ziurtatu dute. Hori dela eta, elikadura-estrategia ezberdinak erabiliz arrain-irinaren kontsumoa murriztu daitekeela ondoriozta daiteke [12].

\section{ONDORIOAK}

Lan honetan, filtro biologikoak eta beharrezko ponpez osatutako akuaponia-sistema bat abian jarri da ortzadar-amuarrain (Oncorhynchus mykiss) eta letxuga (Lactuca Sativa) dentsitate egokiak erabiliz eta arrainen elikagai gisa proportzio ezberdinetan partzialki TM intsektuaren larbak gehituz. Akuaponia-sistemako uraren propietate fisiko-kimikoak aztertzerakoan, orokorrean balio optimo minimoaren nahiz maximoaren arteko balioak lortu dira, akuaponia-sisteman oreka lortu dela bermatuz. Hala ere, aipatu beharra dago TM larbekin elikatutako sistemetan denbora luzeagoa behar izan dela oreka lortzeko.

Ortzadar-amuarrainen eta letxugen hazkuntza aztertzerakoan, akuaponia-sisteman TM intsektu espeziearen larbak proteina iturri gisa arrainirina ordezka dezakeela esan daiteke, lan honetan gauzatu den esperimentuan zehar ortzadar-amuarrainen zein letxugen hazkuntza zein biziraupena bermatu baitira. Hala ere, gehiegizko ordezkapena dela eta, nabarmentzekoak dira amuarrainen hazkuntzan aurkitutako gabeziak.

Ondorioz, lan honetan aurkitu diren gabeziak saihesteko, arrain-irinaren kontsumoa murriztuko duen TM larbez osaturiko pentsu baten ekoizpenaren beharra aurkitu da; izan ere, amuarrainen pentsu ez-jasangarriaren aurrean TM intsektu espeziea intsumo berritzaile zein etorkizun handiko alternatibatzat aurkezten da. Horretarako, lehenik eta behin, amuarrainen beharrak asetzeko intsektuak izan beharreko osagai nutrizionalen inguruan gehiago ikertu beharra dago, hauek intsektuaren habitataren, elikaduraren zein garapen etaparen arabera manipula baitaitezke. Hori horrela izanik, lan honetan, arlo honetan ikerketa gehiago behar den arren, akuaponia-sistemetan pentsu konbentzionalak TM intsektuaren larbekin prestatutako pentsuarekin ordezka daitezkeela ondorioztatzen da. Horrela, arrain-irinean oinarritutako pentsuarekiko menpekotasuna murriztuko litzateke, ekonomia zirkularrean zein jasangarritasunean oinarritutako akuaponia-sistema baten aldeko apustua eginik. 
Landare eta arrainen ekoizpen jasangarrirako akuaponia sistema baten garapena Tenebrio molitor intsektuaren larbak erabiliz

\section{BIBLIOGRAFIA}

[1] FAO. 2018. El estado mundial de la pesca y la acuicultura 2018. Cumplir los objetivos de desarrollo sostenible. Roma (Italia).

[2] APROMAR-ESACUA-FUNDACIÓN OESA. 2013. La acuicultura en España 2013. Madrid (Espainia).

[3] AGUILERA-MORALES, M. E., HERNÁNDEZ-SÁNCHEZ, F., MENDIETA-SÁNCHEZ, E., HERRERA-FUENTES, C. 2012. «Producción integral sustentable de alimentos». Ra Ximhai: revista científica de sociedad, cultura y desarrollo sostenible, $\mathbf{8}, 71-74$.

[4] FAO. 2011. El estado de los recursos de tierras y aguas del mundo para la alimentación y la agricultura. La gestión de los sistemas en situación de riesgo. Organización de las Naciones Unidas para la Alimentación y la Agricultura, Roma, y Mundi-Prensa, Madrid (Espainia).

[5] EUSKO JAURLARITZA. 2015. Agenda Euskadi 2030. Gasteiz (Euskal Herria).

[6] GILSANZ MARTINEZ, J. C. 2007. Hidroponia. Montevideo (Uruguai).

[7] FAO. 2003. Acuicultura: Principales conceptos y definiciones. Madrid (Espainia).

[8] GONZÁLEZ BERMÚDEZ, A. M. 2017. Diseño, construcción y análisis de funcionamiento inicial de un sistema de acuaponía que combina un estanque ornamental con un jardín vertical exterior. Gradu amaierako lana, Universidad de Sevilla (Espainia).

[9] SOMERVILLE, C., COHEN, M., PANTANELLA, E., STANKUS, A., LOVATELLI, A. 2014. Small-scale aquaponic food production. Integrated fish and plant farming. FAO, Roma (Italia).

[10] TACON, A. G., HASAN, M. R., SUBASINGHE, R. P. 2006. Use of fishery resources as feed inputs to aquaculture development: trends and policy implications. FAO, Roma (Italia).

[11] OGUNJI, J. O., KLOAS, W., WIRTH, M., SCHULZ, C., RENNERT, B. 2006. Housefly Maggot Meal (Magmeal): An Emerging Substitute of Fishmeal in Tilapia Diets. Conference on International Agricultural Research for Development. Stuttgart (Alemania).

[12] DE HARO DOMÍNGUEZ, C. 2015. Evaluación de la harina de insectos como fuente alternativa a la harina de pescado en piensos para acuicultura. Doktoretza tesia, Universidad de Almería (Espainia).

[13] FAO. 2013. Edible insects. Future prospects for food and feed security. Roma (Italia).

[14] FAO. 2011. Small-scale rainbowtrout farming. Roma (Italia).

[15] EUSKO JAURLARITZA. 2014. Akuikulturaren Garapenerako Plan Estrategikoa 2014-2020. Gasteiz (Euskal Herria).

[16] CÁCERES GUARNIZ, D. I. 2013. Efecto del agua residual del cultivo de Oreochromis Niloticus «Tilapia» sobre el crecimiento de Lactuca Sativa «Lechuga» en sistema acuapónico continuo. Gradu amaierako lana, Universidad Nacional de Trujillo (Peru). 
Maite Arregi, Beñat Subinas, Oier Elissalt, Oihane Arrieta, Leire Oreja, Maria Jose Barriola, Ainara Saralegi

[17] BELFORTI, M., GAI, F., LUSSIANA, C., RENNA, M., MALFATTO, V., ROTOLO, L., DE MARCO, M., DABBOU, S., SCHIAVONE, A., ZOCCARATO, I., GASCO, L. 2015. «Tenebrio molitor meal in rainbow trout (Oncorhynchus Mykiss) diets: Effects on animal performance, nutrient digestibility and chemical composition of fillets». Italian Journal of Animal Science, 14, 671-676.

[18] BAUTISTA ESPONIZA, H. 2007. Elaboración de una nueva dieta con la inclusión de sangre bovina deshidratada, como fuente de hierro y como equilibrador de perfil aminoacídico para alevines de truchas arco iris Oncorhynechus Mykiss Tandayapa. Gradu amaierako lana, Universidad de las Fuerzas Armadas-ESP (Ekuador).

[19] FAO. 2014. Manual práctico para el cultivo de la trucha arcoíris. Roma (Italia).

[20] IBERIA, P. G. ProfiLux 3.1T, http://www.profilux.es/profilux-3-1t/ (eguneratze data: 2020ko ekainak 17).

[21] SIMÓN, E. W. M., TRELLES, A. Z. 2014. «Sistema acuapónico del crecimiento de lechuga, Lactuca sativa, con efluentes de cultivo de tilapia». Rebiol, 34, 60-72.

[22] MONTAÑA, C. A. 2009. Crecimiento y sobrevivencia en el levante de alevinos de trucha arcoíris (Oncorhynchus Mykiss) en sistemas cerrados de recirculación de agua. Gradu amaierako lana, Universidad Militar Nueva Granada (Kolonbia).

[23] STICKNEY, R. R. 2000. Encyclopedia of aquaculture. John Wiley \& Sons, Inc., New York (AEB).

[24] ALCARRAZ, E., TAPIA, M., BUSTAMANTE, A., TAPIA, O., WACYK, J., ESCALONA, V. 2018. «Evaluación de la concentración de nitratos, calidad microbiológica y funcional en lechuga (Lactuca sativa L.) cultivadas en los sistemas acuapónico e hidropónico». Anales Científicos, 79, 101-110.

[25] DOSSEY, A. T., MORALES-RAMOS, J. A., ROJAS, M. G. 2016. Insects as sustainable food ingredients : Production, processing and food applications. Academic Press, Cambridge (AEB).

[26] NG, W.-K., LIEW, F.-L., ANG, L.-P., WONG, K.-W. 2001. «Potential of mealworm (Tenebrio molitor) as an alternative protein source in practical diets for African catfish, Clarias gariepinus». Aquaculture Research, 32, 273-280. 